\title{
MAGNITUDE OF THE INGLEWOOD, CALIFORNIA, EARTHQUAKE OF JUNE 21, 1920
}

\author{
By C. F. Richter
}

ABSTRACT

\section{Comparison with later earthquakes in the same area indicates a magnitude near 4.9 for the Inglewood, California, earthquake of June 21, 1920.}

\section{INTRODUCTION}

The earthquake which was damaging at Inglewood, a southwestern suburb of Los Angeles, on June 21, 1920, was a minor event. In later years the circumstance has assumed increasing importance; for although the area most affected was then largely rural, it is now almost completely urbanized, and interpretation of the 1920 earthquake is significant in assessing earthquake risk in the metropolitan area.

There has been misunderstanding, sometimes appearing in print, regarding the rating of this earthquake on the instrumental magnitude scale. A little study of descriptive reports such as that of Taber (1920) suggests that the magnitude, in spite of the lack of adequate instrumental data, can be placed in the range from 4.7 to 5.2 .

Nevertheless, a "magnitude" of 8 has sometimes been quoted. Unsuspicious readers have accepted this at second hand as evidence of a major earthquake. The error presumably originated from intensity VIII cited in publications of the Coast and Geodetic Survey (Wood, Allen, and Heck, 1934) and in the catalog by Townley and Allen (1939).

No estimate of magnitude for this event was included in the writer's textbook (Richter, 1958). It seems desirable to repair this omission.

\section{Seismographic Data}

In 1920 no adequate seismographs were in operation in southern California (at Point Loma there were instruments of the West type, of low magnification and uncalibrated). The degree to which the Inglewood earthquake was recorded at distant stations corresponds to what may be expected for a magnitude near 5 . Thus, the International Seismological Summary (Turner ed., 1925) tabulated $P$ as recorded only at Berkeley; the first arrival listed for Tucson is probably one of the $S$ group of waves. Recordings, chiefly of surface waves, increasing in indefiniteness with distance, were reported from Victoria, Chicago, Toronto, Georgetown, Washington, Cheltenham, Ithaca and Ottawa. The Summary assigns an epicenter at $33.0 \mathrm{~N} 121.5 \mathrm{~W}$, which is grossly in error; Taber's mapped epicenter, based on the observed distribution of intensity, is near $33^{\circ} 58^{\prime} \mathrm{N} 118^{\circ} 23^{\prime} \mathrm{W}$. The hour of occurrence was $6: 47$ p.m. Pacific Standard Time, June 21 (02:47 G.C.T. June 22).

The only published seismometric readings appear in the bulletin for the Berkeley station (Bond, 1921). Maximum waves are reported as follows:

$\begin{array}{ccc}\text { Component } & \text { Amplitude (microns) } & \text { Period (seconds) } \\ \text { N-S } & 18.1 & 6 \frac{1}{2} \\ \text { N-S } & 23.4 & 6 \frac{1}{2} \\ \text { E-W } & 14.0 & 6 \frac{1}{2} \\ \text { Z } & 10.4 & 7 \\ & 647 & \end{array}$


Assuming a true maximum ground amplitude in one horizontal component as 20 microns with a period of $6 \frac{1}{2}$ seconds, we may calculate the trace amplitude with which this should appear on the seismogram of a standard torsion seismometer as later developed by Anderson and Wood, with pendulum period 0.8 seconds, damping $h=0.8$, and static magnification 2800 . The result is 0.9 millimeters. If we take the epicentral distance as 560 kilometers and apply the local magnitude scale, we find magnitude 4.8, to which should be added 0.2 as station correction for Berkeley. This result is encouraging, but cannot be given much weight, since there is no assurance that the seismic waves which constituted the maxima on the seismograms at Berkeley would also have written the maxima on torsion-seismometer records.

\section{Comparison With other Events}

Macroseismic data can be used to compare the 1920 earthquake with later ones in the same area for which instrumental magnitudes have been determined. Comparison

TABLE 1

Comparison of the Inglewood Eartheuake of 1920 with Later Events

\begin{tabular}{|c|c|c|c|c|c|c|c|}
\hline \multicolumn{2}{|c|}{ Date } & \multirow{2}{*}{$\frac{\text { P.S.T. }}{18: 47}$} & \multicolumn{2}{|c|}{ Epicenter } & \multirow{2}{*}{$\frac{\text { Max. M.M. }}{\text { VII }}$} & \multirow{2}{*}{$\frac{\text { Radius }}{56 \text { miles }}$} & \multirow{2}{*}{ Magnitude } \\
\hline 1920 & June 20 & & $33^{\circ} 58^{\prime} \mathrm{N}$ & $118^{\circ} 23^{\prime} \mathrm{W}$ & & & \\
\hline 1930 & Aug. 30 & $16: 40$ & 3357 & 11838 & VIII? & 170 & 5.2 \\
\hline 1933 & Oct. 2 & $01: 10$ & 3347 & 11808 & VII- & 80 & 5.2 \\
\hline 1938 & Aug. 30 & $19: 18$ & 3348 & 11814 & VI & 40 & 4.5 \\
\hline 1941 & Oct. 21 & $22: 57$ & 3349 & 11813 & VII & 55 & 4.9 \\
\hline 1941 & Nov. 14 & $00: 41$ & 3347 & 11815 & $\mathrm{VII}^{+}$ & 75 & 5.4 \\
\hline 1944 & June 18 & $16: 03$ & 3352 & 11813 & VII & $70 ?$ & 4.5 \\
\hline 1944 & June 18 & $19: 06$ & 3352 & 11813 & VII & $70 ?$ & 4.4 \\
\hline
\end{tabular}

involves the maximum intensity near the epicenter (in 1920, VII M.M. or VIII R.F.), and the representative radius of the area over which shaking was felt, taking account of the tendency to elongation in some directions, and discarding exceptional localities affected by ground conditions or other special circumstances. Taber (1920) reports that the 1920 shock was felt as far as Riverside and Ventura, distant 56 and 57 miles from Inglewood. Macroseismic information for the later events is taken from files and publications of the Seismological Laboratory at Pasadena; the same data are reproduced, with convenient maps, in successive issues of the serial "United States Earthquakes" issued by the Coast and Geodetic Survey.

The data are shown in Table 1 . No earthquakes suitable for the purpose have been excluded. The apparent abnormality of the radius of perceptibility for the two shocks in 1944 may be connected with occurrence of two nearly equal events three hours apart, affecting public alertness and tending to confuse the record. Otherwise, the basis of comparison is reasonably consistent. The question attached to VIII for the 1930 earthquake is due to the location of the epicenter offshore; VIII was approached at several points on land, so that there is no doubt that this event appreciably exceeded that of 1920. Close correspondence of the data for 1920 with those for 1941, Oct. 21, supports an adopted magnitude of 4.9 for the former. This is not likely to be in error by more than \pm 0.2 . 


\section{REFERENCES}

Bond, L. A. (1921). The registration of earthquakes at the Berkeley station and at the Lick Observatory station from October 1, 1920 to March 31, 1921, Bulletin of the Seismographic Stations, University of California Publications, vol. 2.

Richter, C. F. (1958). Elementary Seismology, Freeman, San Francisco, 768 pp.

Taber, S. (1920). The Inglewood earthquake in southern California, June 21, 1920, Bull. Seism. Soc. Am. 10, 129-145.

Townley, S. D. and M. W. Allen (1939). Descriptive catalog of earthquakes of the Pacific coast of the United States 1769 to 1928, Bull. Seism. Soc. Am. 29, 216.

Turner, H. H., ed. (1925). International Seismological Summary for 1920, University Observatory, Oxford.

Wood, H. O., Allen, M. W. and N. H. Heck (1934). Destructive and near-destructive earthquakes in California and Western Nevada, 1769-1933, U. S. Coast and Geodetic Survey, Special Publication No. 191, Government Printing Office, Washington, p. 18-19.

Seismological Laboratory

California Institute of Technology

Pasadena, California 91109

Division of Geological Sciences

Contribution No. 1696

Manuscript received November 17, 1969. 